"Managing the risk of the community engagement project: SME managerial skills transfer project at UNISA"

AUTHORS Louise van Scheers

Louise van Scheers (2016). Managing the risk of the community engagement

ARTICLE INFO project: SME managerial skills transfer project at UNISA. Problems and Perspectives in Management, 14(4-1), 154-158. doi:10.21511/ppm.14(41).2016.03

DOI http://dx.doi.org/10.21511/ppm.14(4-1).2016.03

RELEASED ON Friday, 23 December 2016

JOURNAL

"Problems and Perspectives in Management"

FOUNDER

LLC "Consulting Publishing Company "Business Perspectives"

NUMBER OF REFERENCES

0

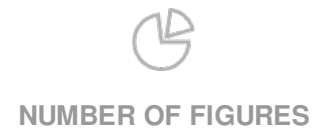

0

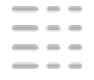

NUMBER OF TABLES

0

(C) The author(s) 2023. This publication is an open access article. 
Louise van Scheers (South Africa)

\title{
Managing the risk of the community engagement project: SME managerial skills transfer project at UNISA
}

\begin{abstract}
The aims of this project are to manage the risk of a community engagement project, improve managerial of SME owners in the Tshwane community and promote CE scholarship engagement. CE opportunities as well as the high failure rate of SMEs motivated the lecturers of the Department Marketing and Retail to initiate training workshops in their community. This CE project SME skills transfer workshops aims to expand the involvement with the community and develop community engagement projects in addition also transfer managerial skills to SME owners in the community.

Quantitative, exploratory research was used in the form of questionnaires with owners of SMEs participating in the workshops. The conducted research established that the most successful advertising medium is wall painting. With this community engagement project it had been reached 200 SMEs. It has been promoted CE scholarship engagement and manage the risk of this project. One of the secondary objectives was to manage the risk of this project. The results in table 1 indicate that the risk is managed adequately. This project is not considered as a high risk project for the university. The aims were achieved as evidence of transferring of managerial skills; managing risk of the project, promotion of CE scholarship and publishing articles through our CE project were achieved.
\end{abstract}

Keywords: SME managerial skills transfer, risk management, community engagement, Tshwane community, advertising media, advertising key success factors, word of mouth.

JEL Classification: M37.

\section{Introduction}

Community engagement (CE) as defined by $\mathrm{CE}$ scholars Fawcett, Paine-Andrews, Francisco, Schultz, Richter, Lewis, and Williams (2011), Harris, Berkley, Fisher, Lopez (2011)/Foxall, Goldsmith and Brown (2008), Handley, Pasick, Potter, Oliva, Goldstein and Nguyen (2010) as the process of working collaboratively with and through groups of people affiliated by geographic proximity, special interest, or similar situations to address issues affecting the well-being of those people. It is a powerful vehicle for bringing about environmental and behavioral changes that will improve the health of the community and its members. It often involves partnerships and coalitions that help mobilize resources and influence systems, change relationships among partners, and serve as catalysts for changing policies, programs and practices. Cavaye $(2001 ; 2011)$ explains $C E$ as a planned process with the specific purpose of working with identified groups of people with special interest or identifies to address issues affecting their well-being. The linking of the term "community" to "engagement" serves to broaden the scope, shifting the focus from the individual to the collective, with the associated implications for inclusiveness to ensure consideration is made of the diversity that exists within any community as the study by Handley, Pasick, Potter, Oliva, Goldstein, and Nguyen (2010) established.

(C) Louise van Scheers, 2016.

Louise van Scheers, Department of Marketing and Retail, University of South Africa, South Africa.
The University of South Africa consider community engagement is one of the three interconnected pillars of academic endeavour namely tuition, research and community engagement (CE). The implementation of academic community engagement requires it to be professional, knowledgeable and well organized. Community engagement involves two main players: community and academic lecturers. The Marketing and Retail Department, University of South Africa decided to form academic partners with the Small and Medium Enterprises (SME) owners in the Tshwane community. As academic partners we can enhance SME managerial skill transfer and identity advertising challenges and thereby enhances our community involvement and participation in the Tshwane community.

This partnership enables us to increase their knowledge of managerial and marketing related issues as well as create opportunities for research and publication. We present skills transfer workshops presented on a monthly basis with Prof Louise van Scheers and Marjorie Mtjekelo as project leaders. The aim of this project is to improve managerial of SME owners in the Tshwane community and promote CE scholarship engagement. As we believe community engagement should benefit the community as well as our department we use these workshops as an opportunity to develop SME skills to improve the community; liaise with industry; create a culture of teamwork at the department as well as use the research to publish research articles in accredited journals. These workshops are presented on a monthly basis with Prof Louise van Scheers as project leader. The essential argument of this paper 
is that it supports the thinking and values which underpin the current driving force at the University of South African to develop CE by collaborating with SME in our community.

This research report aims to expand our involvement with our community and develop community engagement projects as well as transfer managerial and marketing skills to SME owners in our community (Tshwane municipality area) as well as manage the risk of this project. Secondary objective was to determine the advertising media that SME owners are using to promote sustainable SME development and to reach the aim of the study, the objectives of this study were to:

- expand our involvement with our community and develop community engagement projects;

- manage the risk of this community engagement project;

- transfer managerial skills to SME owners in our community (Tshwane municipality area);

- promote CE scholarship engagement;

\section{Research methodology}

Secondary and primary sources were used to gather information to analyze marketing skills of Spaza shops. Secondary data is the cheapest and easiest means of gathering information. The main sources of secondary sources were journals, articles, press reports, books, and research studies. In obtaining primary data a questionnaire will be used. The purpose of this research was to determine advertising media that SME workshop participants use in the Tshwane community. 200 SME workshop participants from the Tshwane community completed the questionnaire during the SME workshops between March and May 2015. Quantitative, exploratory research was chosen as research design. The questionnaire questions were developed to achieve the objectives of the study as well as contributing to the phenomenon of interest.

\section{Literature review}

2.1. Community engagement (CE). Fawcett (2011), Harris (2008), Handley (2010) describe CE as the collaboration of universities and their communities for the mutually beneficial exchange of knowledge and resources in a context of partnership and reciprocity. This definition adheres to key principles of and scholarship involvement that demonstrates a high level of discipline-related proficiency, is creative or original, is amendable to documentation, may be peer or constituent-reviewed, and has significant impact on research knowledge. Bartel, Krasny, and Harrison (2003), Foxall (2008) emphasize that CE, community, university knowledge and resources are connected to enhance scholarship, research, and creative activity; address critical managerial issues and contribute to the wellbeing of the community.

2.2. Community engagement scholarship. The term community-engaged scholarship as Ahmed and Palermo (2010), Abrams, Townson, Williams and Sandmann (2006), Alter (2003) state refers to research activities and teaching by lecturers in collaboration with community members and that embody the characteristics of both community engagement (reciprocal partnerships) and scholarship (demonstrates current knowledge of the discipline, invites peer collaboration and review, is open to critique, is presented in a form that others can build on, involves inquiry). The lectures of the Department Marketing \& Retail at the University of South Africa recognize CE scholarships are essential to the translation of research into meaningful improvements in our community. Community-based teaching and research are central to goals such as eliminating teaching disparities and improving the economic vitality of communities and are increasingly being embraced as central to the academic mission of South African universities. Community-engaged research according to Handley, Pasick, Potter, Oliva, Goldstein, and Nguyen (2010) means to collaborate fully in all aspects of research which include defining study questions, writing the proposal, designing the methods, implementing the research project, analyzing the results and publicize the findings in accredited journals At the University of South Africa (adapted from Unisa website; 2012) we strive to:

- Integrate community engagement into our educational experience.

- Encourage simultaneously pursue lectures interests, educational goals, and make a difference in our community.

- Provide a foundation of analytical, reflective, interpersonal, and leadership skills through realworld experience.

- Supports the University's mission of public engagement and outreach by fostering connections between our University, our students and our community.

2.3. Models of community engagement. The components of the model of engagement as Hashagen (2002) explains include the following elements such as capacity building skills, inclusion building equality; and Resources sustaining change. Our community project is included under the capacity building skills which indicates interactive or partnership building. Our project's main aim is therefore to provide support to community to have equivalent access to expertise, advice and training. 
2.4. Risk management of a UNISA community engagement project. Risk management can be defined as the process of identification, analysis and either acceptance or mitigation of uncertainty in investment decision-making when starting a new community engagement project. Risk management occurs when a project manager analyzes and attempts to quantify the potential for losses in a project investment and then takes the appropriate action (or inaction) given their investment objectives and risk tolerance. Inadequate risk management can result in severe consequences for the university as well as the community. The goal of risk management is to improve performance by acknowledging and controlling risk, which improves the Unisa's ability to avoid unpleasant surprises that can occur during the implementation of a service-learning module or project. This helps UNISA to take control of the risks that cannot be avoided. Risks can be categorized into different types and levels (people, property, income and goodwill). The simplest definition, however, is "the possibility of loss, injury, disadvantage or destruction".

Community interaction is a core function of University of South Africa (UNISA). This development is in line with the statement of the National Plan for Higher Education which indicates that community engagement is currently not viewed as an option in South African Higher Education, but as an essential part of scholarship. The general vision for community engagement in South Africa is based on the White Paper on the Transformation of Higher Education (1997). SU has committed itself to the integration of its three core functions, namely teaching and learning, research and community interaction (UNISA also adopted the concept community interaction in its policy rather than community engagement). In its Community Interaction Policy, the University commits itself to the transformation process of higher education and to be an active role player in the development of South African society. One of the secondary objectives of this paper is to establish to manage risk of the SME managerial skills transfer project which is a community engagement project at UNISA.

2.5. The Tshwane community SME managerial skills transfer project. The project started with an idea to get the department involves in the Tshwane community and the community is our community. We completed a situational analysis which indicated that SME owners lack managerial skills and with this in mind the SME managerial skills transfer project was born.
The Tshwane community is being reinvented as a feasible centre of commercial and cultural activity (ANON, 2009, Thale, 2009). The government has made attempts to upgrade the overall standard of living in the Tshwane community by planting trees and providing basic amenities to parts of the township (ANON, 2009). Thale (2009) explains that the Baralink project is an example of such new developments, promising to improve the overall infrastructure of the community and encourage the growth of a viable business environment. This activity, according to Thale (2009), will lead to the emergence of a multitude of small businesses in the community and therefore a comprehensive advertising campaign is vital for these new businesses to survive and succeed.

2.6. SMEs in the Tshwane community. The Tshwane community is fast becoming a commercial hub with an increasing number of small businesses opening every year. This has led to increased competition in the community and therefore it has become increasingly important for businesses to differentiate themselves from their competitors. This can be done effectively through the use of advertising therefore it is necessary to be able to identify relevant advertising opportunities for these businesses. Media is defined as a communications channel or a group of channels used to convey information, news, entertainment, and advertising messages to an audience (Du Plessis et al., 2009, p. 56). Choosing the right media to carry a company's message is critical for the success for a company's advertising (ANON, 2001 ; 2011). There are two major advertising media: broadcast media such as television and radio, and print media such as newspapers, magazines, billboards, direct mail and leaflets (Du Plessis et al., 2009, p. 41). Television, radio, newspapers, magazines, out of home advertising, direct response and direct mail advertising are all forms of advertising media (Russell et al., 2006, p. 221). Mass media such as newspapers, magazines, radio, and television are especially well suited for delivering advertisements (Sissors \& Bumba, 2006, p. 7).

\section{Research findings}

3.1. Risk management of the SME managerial skills transfer project. Table 1 gives a summary of the risks of the SME managerial skills transfer project and how these possible risks were managed. 
Table 1. Summary of the risks of the SME managerial skills transfer project

\begin{tabular}{|c|c|c|c|c|}
\hline & Risk category & Risk description & Risk assessment & Control activity/treatment \\
\hline 1. & $\begin{array}{l}\text { Quality community } \\
\text { engagement project }\end{array}$ & $\begin{array}{l}\text { The risk of the SME managerial skills transfer pro- } \\
\text { ject may not meet the requirements of the univer- } \\
\text { sity's CE Policy and may not be aligned with specific } \\
\text { disciplines as well as the global and local develop- } \\
\text { mental objectives. }\end{array}$ & Low & $\begin{array}{l}\text { Review and Quality Assurance sub-committee scruti- } \\
\text { nise project registrations documents and monitor } \\
\text { implementation to ensure compliance }\end{array}$ \\
\hline 2. & $\begin{array}{l}\text { Quality employees and } \\
\text { students involved in } \\
\text { community engage- } \\
\text { ment initiatives }\end{array}$ & $\begin{array}{l}\text { Unethical or inefficient employees and students may } \\
\text { be involved in projects resulting in negative out- } \\
\text { comes }\end{array}$ & Moderate & $\begin{array}{l}\text { Encourage ethical behavior and conduct consistent } \\
\text { with code of conduct precepts of the institution. }\end{array}$ \\
\hline 3. & $\begin{array}{l}\text { Quality integration of } \\
\text { CE with the other } \\
\text { core functions (tuition } \\
\text { and research) }\end{array}$ & $\begin{array}{l}\text { The projects may not be adding value to the other } \\
\text { core functions of the institution thereby not being a } \\
\text { scholarly activity }\end{array}$ & Low & $\begin{array}{l}\text { Review project periodically and attend community } \\
\text { activity. Inspect reports for evidence of integration and } \\
\text { perform follow up activity. }\end{array}$ \\
\hline 4. & $\begin{array}{l}\text { Quality tuition content } \\
\text { and research pro- } \\
\text { duced as result of } \\
\text { community engage- } \\
\text { ment }\end{array}$ & $\begin{array}{l}\text { There may be a poor reciprocal relationship be- } \\
\text { tween the institution and the target community } \\
\text { resulting in inadequate input to tuition and research }\end{array}$ & Low & $\begin{array}{l}\text { Periodically enquire of project leader and review } \\
\text { submitted reports to verify reciprocity and input into } \\
\text { tuition and research. }\end{array}$ \\
\hline 5. & $\begin{array}{l}\text { Quality student } \\
\text { initiatives that en- } \\
\text { hance learning \& } \\
\text { graduateness }\end{array}$ & $\begin{array}{l}\text { There may be limited or no CE initiatives that con- } \\
\text { sider students, learning or graduateness }\end{array}$ & Moderate & $\begin{array}{l}\text { Inspect project register, submitted reports and any } \\
\text { other relevant documentation for evidence of student } \\
\text { community engagement involvement and link to learn- } \\
\text { ing and graduateness. }\end{array}$ \\
\hline 6. & $\begin{array}{l}\text { Quality stakeholder } \\
\text { relationships and mu- } \\
\text { tually beneficial part- } \\
\text { nerships }\end{array}$ & $\begin{array}{l}\text { Communities and partners may withdraw from } \\
\text { participation, be hostile towards project leaders or } \\
\text { have no interest in projects, or breakdown in rela- } \\
\text { tions may cause reputational damage }\end{array}$ & Moderate & $\begin{array}{l}\text { Ensure completion and loading of memoranda of agree- } \\
\text { ments or understanding to manage relationships with key } \\
\text { stakeholders. Perform project visits to gain qualitative } \\
\text { perspective of community perception if initiatives }\end{array}$ \\
\hline 7. & $\begin{array}{l}\text { Quality financial } \\
\text { planning, expenditure } \\
\text { management and re- } \\
\text { porting }\end{array}$ & $\begin{array}{l}\text { Lack of financial resources or annual spending may } \\
\text { result in project not being funded or reduction of } \\
\text { allocations for project activities }\end{array}$ & High & $\begin{array}{l}\text { Inspect budgets allocated for adequacy and refine } \\
\text { when necessary. Engage project leaders regarding } \\
\text { expenditure management and adequate resource } \\
\text { utilisation. Centralise financial processing of requests } \\
\text { to enhance monitoring and reporting functions }\end{array}$ \\
\hline 8. & $\begin{array}{l}\text { Quality communication } \\
\text { and profiling of com- } \\
\text { munity engagement } \\
\text { initiatives }\end{array}$ & $\begin{array}{l}\text { Poor communication with relevant stakeholder may } \\
\text { diminish the profile of CE and awareness of suc- } \\
\text { cesses }\end{array}$ & Low & $\begin{array}{l}\text { Develop marketing and communication plan to profile } \\
\text { community engagement and implement accordingly } \\
\text { through various media and use of key stakeholder } \\
\text { platforms. }\end{array}$ \\
\hline
\end{tabular}

3.2. Purpose of impact as criteria. The purpose of IMPACT as criteria of selecting CE projects at UNISA is to ensure that the projects contribute positively and

have long term effects on communities. In addition to that they must be informed on a national level by the NDP and on institutional level by UNISA MDG.

Table 2. Purpose of impact as criteria

\begin{tabular}{|l|l|l|l|l|}
\hline & \multicolumn{1}{|c|}{ Criteria } & \multicolumn{1}{|c|}{ Aim/Definition } & \multicolumn{1}{|c|}{ Measure } & MDG/NDP \\
\hline 1 & Sustainability & The project should create visiable impact on the CE environment and societies. & $1-5$ years & $1,2,7 \& 8$ \\
\hline 2 & Empowerment & Transfer and impart skills and knowledge for beneficiaries to be independent. & $\begin{array}{l}\text { Pre- and post questionnaires to } \\
\text { measure impact }\end{array}$ & 8 \\
\hline 3 & $\begin{array}{l}\text { Create } \\
\text { change }\end{array}$ & $\begin{array}{l}\text { To create social and economic changes, taking cognisance of the benefits for partici- } \\
\text { pants and communities }\end{array}$ & $\begin{array}{l}\text { Pre- and post questionnares to } \\
\text { measure impact }\end{array}$ & $1 \& 2$ \\
\hline 4 & Collaboration & $\begin{array}{l}\text { To forge and map a rapport with local authorities in an attempt to secure and acquire } \\
\text { resources for the success of the projects. }\end{array}$ & $\begin{array}{l}\text { Partnership aggreements and } \\
\text { contracts. }\end{array}$ & $1,2,7 \& 8$ \\
\hline 5 & Researchable & $\begin{array}{l}\text { It should enable relevant stakeholders to explore innovative and ground breaking } \\
\text { solutions to social ills and challenges. }\end{array}$ & $\begin{array}{l}\text { Submit articles to accredited jour- } \\
\text { nals }\end{array}$ & $1 \& 2$ \\
\hline
\end{tabular}

\section{Conclusion}

The aim and objectives for this research were to expand our involvement with our community; develop community engagement projects; promote $\mathrm{CE}$ scholarship engagement; manage the risk of this project and transfer managerial skills to SME owners in our community. With this community engagement project we have reached 200 SMEs. We have promoted CE scholarship engagement and manage the risk of this project. The aim of this reseaarch was to manage the risk of this project. The results in table 1 indicate that the risk is managed adequately. This project is not considered as a high risk project for the university.

The aim was achieved as evidence of transferring of managerial skills; managing risk of the project, promotion of CE scholarship and publishing articles through our CE project were provided. 


\section{References}

1. Anon

(2001;

2009).

Advertising objectives.

Available at: http://www.examstutor.com/business/resources/studyroom/marketing/advertising/2-advertisingobjectives.php?style=. Accessed on18 Apr 2012.

2. Anon. (2009). The making of The Tshwane community. Available at: http://www.joburg.org.za/TheTshwanecommunity/overview.stm. Accessed on 15 Apr 2012.

3. Anon. (2009). What are the advantages of advertising on the Internet? Available at: http://www.happyonline.co.uk/tutorial/advertising.htm. Accessed on 10 May 2012.

4. Anon. (2012). CTN launches living township billboards. Biz-Community. Available at: http://www.bizcommunity.com/Article.aspx?c=70\&1=196\&ai=4796. Accessed on May 2012.

5. Bradley, H.B., Com Hons. (2014). Marketing Report. University Of South Africa.

6. Ahmed, S.M. and Palermo, A.S. (2010). Community Engagement in Research: Frameworks for Education and Peer Review, American Journal of Public Health, Published online ahead of print June 17, 2010. Available at: http://ajph.aphapublications.org/cgi/reprint/AJPH.2009.178137v1.

7. Abrams, E., Townson, L., Williams, J.E. and Sandmann, L.R. (2006). Engaged Faculty at the University of New Hampshire: The Outreach Scholars Academy, Journal of Higher Education Outreach and Engagement, 11 (4), pp. 27-39.

8. Alter, T.R. (2003). Where is Extension Scholarship Falling Short, and What Can We Do About It? Journal of Extension, 41 (6).

9. Barker, D. (2004). The Scholarship of Engagement: A Taxonomy of Five Emerging Practices, Journal of Higher Education Outreach and Engagement, 9 (2), pp. 123-137.

10. Bartel, A.S., Krasny, M. and Harrison, E.Z. (2003). Beyond the Binary: Approaches to Integrating University Outreach with Research and Teaching, Journal of Higher Education Outreach and Engagement, 8 (2), pp. 89-104.

11. Cavaye, Dr. J. (2001). Community engagement framework project: scoping and review paper, Cavaye Community Development/CEO Committee on Land Resources, Queensland, citing OECD (2001) Engaging Citizens in policymaking: information, consultation and public participation, PUMA Policy brief No 10, July 2001, Organization for Economic Co-operation and Development.

12. Davie, L. (2012). The Tshwane community, city of contrasts. Available at: http://www.joburg.org.za/december/The Tshwane community.stm. Accessed on 13 Apr. 2012.

13. Dirksen, C.J., Kroeger, A. \& Nicosia, F.M. (2003). Advertising: Principles and Management Cases. Illinois: Richard D. Irwin. INC.

14. Dupont, L. (2002). The six effects of repetition. Available at: http://bellzinc.sympatico.ca/en/content/503046?skin=sli. Accessed on May 2012.

15. Du Plessis, F., Bothma, N., Jordaan, Y. \& van Heerden, N. (2009). Integrated Marketing Communication. Claremont: New Africa.

16. Egelhoff, T. (2004). How to develop a successful advertising campaign. Available at: http://www.smalltownmarketing.com/adprogram.html. Accessed on April 2012.

17. Foxall, G., Goldsmith, R. \& Brown, S. (2008). Consumer psychology for marketing. $2^{\text {nd }}$ edition. London: Thomson.

18. Handley, M., Pasick, R., Potter, M., Oliva, G., Goldstein, E., Nguyen, T. (2010). Community-Engaged Research: A Quick-Start Guide for Researchers. San Francisco: Community Engagement Program Clinical \& Translational Science Institute at the University of California.

19. Maravilla, N. (2000). The perceived value of advertising. Available at: http://www.powerhomebiz.com/vo1/advalue.htm. Accessed on 10 Sep 2004.

20. McKnight, J.L., Kretzmann, J. (2011). Mapping community capacity. Evanston (IL): Center for Urban Affairs and Policy Research, Northwestern University.

21. McMillan, B., Florin, P., Stevenson, J., Kerman, B., Mitchell, R.E. (1995). Empowerment praxis in community coalitions, American Journal of Community Psychology, 23 (5), pp. 699-728.

22. Thale, T. (2009). The Tshwane community's gravel roads to become history. Available at: http://www.tshwane.org.za. Accessed on 13 Apr. 2012. 